\title{
Hubungan Pengetahuan Ibu dan Dukungan Suami dengan Penggunaan Kontrasepsi Intra Uterine Device (IUD)
}

\section{Sri Handayani ${ }^{1}$,Turiyani ${ }^{2}$ \\ Universitas Kader Bangsa Palembang ${ }^{12}$}

Informasi Artikel :

Diterima : 31 Maret 2021

Direvisi : 15 April 2021

Disetujui : 29 Mei 2021

Diterbitkan : 15 Juni 2021

"Korespondensi Penulis : sri.handayani144@yahoo.com

\section{A B S T R A K}

Semakin meningkatnya laju pertambahan penduduk $1,49 \%$ per tahun sehingga rata-rata wanita subur melahirkan 2,6 anak. Tujuan penelitian ini untuk mengetahui hubungan antara pengetahuan ibu dan dukungan suami dengan penggunaan kontrasepsi Intra Uterin Device (IUD) di Puskesmas Pedamaran Timur. Metode yang digunakan merupakan penelitian kuantitatif dengan desain penelitian cross sectional dimana penelitian dilakukan dengan mengukur variabel independent dan dependent dalam waktu bersamaan. Populasi dalam penelitian ini adalah seluruh ibu yang menjadi akseptor KB dengan sampel 47 akseptor KB. Hasil analisis menunjukkan ada hubungan pengetahuan ibu dan dukungan suami dengan penggunaan kontrasepsi Intra Uterin Device (IUD) di Puskesmas Pedamaran Timur kabupaten OKI Tahun 2018. Penelitian ini menyarankan kepada petugas kesehatan untuk lebih mensosialisasikan pemberian informasi dan pelayanan KIE khususnya mengenai kontrasepsi yang aman pada masyarakat terutama IUD agar metode yang dipilih rasional, efektif, efisien dan sesuai dengan perencanaan keluarga.

Kata Kunci : Penggunaan IUD, Pengetahuan Ibu Dan Dukungan Suami

\section{ABSTRACT}

The increasing rate of population growth by $1.49 \%$ per year so that the average fertile woman gives birth to 2.6 children. The purpose of this study was to determine the relationship between maternal knowledge and husband's support with the use of Intra-Uterine Contraceptive Devices (IUDs) at Puskesmas Pedamaran Timur. The method used is a quantitative study with a cross-sectional research design where the study was conducted by measuring the independent and dependent variables at the same time. The population in this study were all mothers who were family planning acceptors with a sample of 47 family planning acceptors. The results of the analysis show that there is a relationship between mother's knowledge and husband's support with the use of IntraUterine Contraceptive Devices (IUD) at the Pedamaran Timur Puskesmas in OKI district in 2018. This study suggests health workers to further socialize the provision of information and IEC services, especially regarding safe contraception in the community. especially the IUD so that the method chosen is rational, effective, efficient and in accordance with family planning.

Keywords : IUD Use, Mother's Knowledge And Husband's Support

\section{PENDAHULUAN}

Derajat kesehatan merupakan salah satu Menurut World Health Organization
(WHO) (2014) penggunaan kontrasepsi telah meningkat dibanyak bagian dunia, terutama di Asia dan Amerika Latin dan terendah di Sub-Sahara Afrika. Secara global, pengguna 
kontrasepsi modern telah meningkat tidak signifikan dari 54\% pada tahun 1990 menjadi $57,4 \%$ pada tahun 2014. Secara regional, proporsi pasangan usia subur 15-49 tahun melaporkan penggunaan metode kontrasepsi modern telah meningkat minimal 6 tahun terakhir. Di Afrika dari 23,6\% menjadi 27,6\%, di Asia telah meningkat dari 60,9\% menjadi 61,6\%, sedangkan Amerika latin dan Karibia naik sedikit dari $66,7 \%$ menjadi $67,0 \%$.

Jumlah penduduk yang terus meningkat merupakan masalah besar bagi negara-negara di dunia, khususnya negara berkembang. Indonesia merupakan negara berkembang dengan jumlah penduduk terbesar ke empat setelah Cina, India dan Amerika Serikat. Laju pertumbuhan Penduduk (LPP) sebesar 1,49\% dan jumlahnya akan terus bertambah sesuai dengan laju pertumbuhan penduduk. Laju pertambahan penduduk $1,49 \%$ per tahun. Dengan jumlah laju pertumbuhan sebanyak itu, rata-rata wanita subur melahirkan 2,6 anak. Mesti sesuai dengan target, rata-rata wanita melahirkan 2,1 anak dengan begitu laju pertumbuhan penduduk bisa ditekan mencapai angka ideal, yakni sekitar satu sampai dua juta pertahun sesuai dengan target di 2025,

Data SDKI menunjukkan tren prevalensi penggunaan kontrasepsi atau Contraceptive Prevalence Rate (CPR). Persentase wanita kawin umur 15-49 yang menggunakan alat/cara KB, Suntik KB (29\%) merupakan alat/cara KB yang paling banyak digunakan oleh wanita kawin, diikuti oleh pil (12\%), susuk KB dan IUD (masingmasing 5\%), dan MOW (4\%). Bersama MOP, susuk KB, IUD dan MOW merupakan metode kontrasepsi jangka panjang (MKJP) yang dianjurkan penggunaannya dalam Program KKBPK. Dengan demikian, terdapat 14 persen wanita yang menggunakan MKJP (SDKI, 2017)

Data Provinsi Sumatera Selatan, jumlah akseptor aktif tahun 2016 sebanyak 910.346 akseptor dari 1.264.471 pasangan usia subur. Untuk pemakaian kontrasepsi sebagai berikut : Suntik 43,35 persen (394.662 peserta), Pil
35,82 persen (326.066 peserta), Implant 8,882 persen (80.863 peserta), IUD 4,48 persen (40.811 peserta), MOW 1,67 persen (15.170 peserta), MOP 0,04 persen (409 peserta), Kondom 5,75 persen (52.365 peserta) (Dinkes Provinsi SUMSEL, 2017).

Data kota Palembang jumlah akseptor sebanyak 272.628 orang, peserta KB aktif sebanyak 224.474 orang, jumlah Suntik 32,10 persen (87.529 peserta), Pil 21,41 persen (58.394 peserta), Implant 10,24 persen (28.425 peserta), IUD 6,60 persen (17.995 peserta), MOW 5,29 persen (14.428 peserta), MOP 0,37 persen (1024 peserta), Kondom 16,679 persen (Profil Dinkes Kota Palembang, 2017)

Di Pedamaran Timur Kabupaten OKI, perserta KB Aktif MKJP pada tahun 2017 berjumlah 1454 orang yaitu suntik 886 yaitu 60,9 persen, IUD 30 yaitu 2,06 persen, MOW 36 yaitu 2,47 persen, implant 256 yaitu 10,7 persen, MOP 1 yaitu 0 persen, kondom 66 yaitu 4,53 persen, pil 279 yaitu 19,1 persen. (Pedamaran Timur Kabupaten OKI).

Berdasarkan penelitian Sri Mularsih, dkk (2018) hasil analisis data penelitian menggunakan uji bivariat Chi Square yang dilanjutkan dengan uji Kolmogorov Smirnov, diperoleh hasil bahwa ada hubungan yang bermakna antara tingkat pengetahuan ibu PUS tentang kontrasepsi AKDR dengan pemilihan kontrasepsi AKDR, dengan nilai $p$ $=0,000$.

Begitu juga dengan hasil penelitian Rahayu (2018) bahwa dari Uji statistic ChiSquare didapatkan hasil ada hubungan pengetahuan Pasangan Usia subur dengan Penggunaan Kontrasepsi IUD di Nagari Andalas Baruh Bukit Kecamatan Sungayang Kabupaten Tanah Datar dimana nilai $\mathrm{p}=$ 0,050 .

Hasil penelitian Pitriani (2015) juga menunjukkan ada hubungan antara pengetahuan dengan penggunaan kontrasepsi IUD $(\mathrm{p}$ value $=0,036)$.

Kurangnya pengetahuan pada calon akseptor sangat berpengaruh terhadap pemakaian kontrasepsi. Dari beberapa temuan fakta memberikan implikasi program, 
yaitu manakala pengetahuan dari wanita kurang maka penggunaan kontrasepsi terutama metode AKDR menurun. Jika hanya sasaran para wanita saja selalu diberi informasi, sementara para suami kuranng pembinaan dan pendekatan, suami kadang melarang istrinya karena faktor ketidaktahuan dan tidak ada komunikasi untuk saling memberikan pengetahuan (Aspuah, 2010).

Hasil penelitian Ismi Cipta Andini (2017) bahwa Ada hubungan dukungan suami dengan pemilihan kontrasepsi IUD di Puskesmas Tempel I Sleman Yogyakarta tahun 2017 dengan hasil uji statistik yang signifikan $p$-value $0,000<0,05$.

Hasil penelitian Sulastri 2014 juga menyatakan bahwa ada hubungan yang signifikan antara dukungan suami dengan minat ibu dalam pemakaian kontrasepsi IUD di Bergas dengan uji Chi Square didapat nilai $\chi^{2}$ hitung sebesar 10,162 dengan $p$-value $0,006<\alpha(0,05)$,

Penelitian Bernadus dkk (2013) didapatkan hasil bahwa dukungan suami mempunyai hubungan yang bermakna dengan pemilihan AKDR di Puskesmas Jailolo. Berdasarkan hasil uji statistik yang dilakukan diketahui $\mathrm{p}=0,041(\mathrm{p}<0,05)$.

Berdasarkan penelitin Rahayu (2012) didapatkan hasil uji statistik $P$ Value 0,004 berarti ada hubungan antara dukungan suami dengan penggunaan kontrasepsi IUD pada akseptor wanita.

Dukungan suami adalah sokongan/penunjang atau bantuan suami sebagai pasangan hidup dari akseptor dalam menentukan keputusan terhadap tindakan yang akan dilakukan yaitu memilih kontrasepsi yang digunakan (Rodiani, dkk, 2017).

Kontrasepsi tidak dapat dipakai istri tanpa adanya kerjasama suami dan saling percaya. Idealnya pasangan suami istri harus memilih metode kontrasepsi yang terbaik, saling bekerjasama dalam pemakaian, membayar biaya pengeluaran untuk kontrasepsi, dan memperhatikan tanda bahaya pemakaian (Hartanto, 2011).
Tujuan penelitian ini adalah untuk mengetahui hubungan Pengetahuan ibu, dan dukungan suami dengan penggunaan Intra Uterine Device (IUD) di Puskesmas Pedamaran Timur Kab. OKI Tahun 2018.

\section{METODE PENELITIAN}

Metode penelitian ini menggunakan kuantitatif dengan pendekatan "Cross Sectional" dimana variabel-variabel independen (pengetahuan ibu dan dukungan suami) dan variabel dependen (penggunaan Intra Uterine Device (IUD) dikumpulkan dalam waktu yang bersamaan. Populasi dalam penelitian ini adalah seluruh ibu yang menjadi akseptor KB di Puskesmas pedamaran timur Kabupaten OKI pada bulan Januari sampai Juni 2018 berjumlah 1681 akseptor. Pengambilan sampel dilakukan dengan cara Accidental Sampling. Penentuan besar sampel minimal dalam penelitian ini dihitung dengan rumus Lemeslow, didapatkan jumlah sampel 47 responden. Pengumpulan data dikumpulkan melalui data primer dan data sekunder yang di olah melalui Editing, Coding, Entry, dan Cleaning, kemudian di analisis dengan menggunakan analisis univariat dan bivariat.

\section{HASIL PENELITIAN}

\section{AnalisisUnivariat}

Tabel 1 Distribusi Frekuensi Berdasarkan Penggunaan Kontrasepsi intra Uterine Device (IUD) di Puskesmas Perdamaran Timur Kab. OKI Tahun 2018

\begin{tabular}{llcc} 
No. & $\begin{array}{c}\text { Kontrasepsi } \\
\text { IUD }\end{array}$ & $\begin{array}{c}\text { Frekuensi } \\
(\mathbf{N})\end{array}$ & $\begin{array}{c}\text { Persentase } \\
(\boldsymbol{\%})\end{array}$ \\
1. & Ya & 21 & 44,7 \\
2. & Tidak & 26 & 55,3 \\
& Jumlah & 47 & 100 \\
\hline
\end{tabular}

Berdasarkan Tabel 1 distribusi frekuensi responden berdasarkan kontrasepsi IUD di Puskesmas Pedamaran Timur dapat disimpulkan bahwa sebagian besar responden tidak menggunakan kontrasepsi IUD sebanyak 26 responden $(55,3 \%)$. 
Jurnal Kebidanan : Jurnal Medical Science Ilmu Kesehatan Akademi Kebidanan Budi Mulia Palembang Volume.11 No.1, Juni 2021

Available online http://journal.budimulia.ac.id/

Tabel 2 Distribusi Frekuensi Berdasarkan Pengetahuan di Puskesmas Pedamaran Timur Kab. OKI Tahun 2018

\begin{tabular}{|c|c|c|c|}
\hline No. & Pengetahuan & $\begin{array}{l}\text { Frekuensi } \\
(\mathbf{N})\end{array}$ & $\begin{array}{c}\text { Persentase } \\
(\%)\end{array}$ \\
\hline 1. & Baik & 30 & 63,8 \\
\hline \multirow[t]{2}{*}{2.} & Kurang Baik & 17 & 36,2 \\
\hline & Jumlah & 47 & 100 \\
\hline \multicolumn{4}{|c|}{$\begin{array}{l}\text { Berdasarkan Tabel } 2 \text { di atas dapa } \\
\text { t bahwa dari } 47 \text { responden dengan } \\
\text { etahuan yang baik sebanyak } 30 \text { orang } \\
\% \text { ) lebih besar dibandingkan responden } \\
\text { berpengetahuan kurang baik yaitu } 17 \\
(36,2 \%) \text {. }\end{array}$} \\
\hline
\end{tabular}

Tabel 3 Distribusi Frekuensi Berdasarkan Dukungan Suami di Puskesmas Pedamaran Timur Kab. OKI Tahun 2018

\section{Analisis Bivariat}

Tabel 4 Distribusi Responden Berdasarkan Tingkat Pengetahuan dengan Kontrasepsi Intra Uterine Device (IUD) di Puskesmas Pedamaran Timur Tahun 2018

\begin{tabular}{|c|c|c|c|c|c|c|c|c|}
\hline \multirow{3}{*}{$\begin{array}{l}\mathbf{N} \\
\mathbf{0}\end{array}$} & \multirow[t]{3}{*}{ Tingkat Pengetahuan } & \multicolumn{4}{|c|}{ Kontrasepsi IUD } & \multirow{2}{*}{\multicolumn{2}{|c|}{ Total }} & \multirow[t]{3}{*}{ P Value } \\
\hline & & \multicolumn{2}{|c|}{ Ya } & \multicolumn{2}{|c|}{ Tidak } & & & \\
\hline & & $\mathbf{n}$ & $\%$ & $\mathbf{N}$ & $\%$ & $\mathbf{N}$ & $\%$ & \\
\hline 1 & Baik & 18 & 60,0 & 12 & 40,0 & 30 & 100 & 0,012 \\
\hline 2 & Kurang Baik & 3 & 17,6 & 14 & 82,4 & 17 & 100 & Bermakna \\
\hline & Jumlah & 21 & & 26 & & 47 & & \\
\hline
\end{tabular}

Berdasarkan hasil tabel diatas, dapat dilihat dari 30 responden dengan ibu yang berpengetahuan baik menggunakan kontrasepsi IUD sebanyak 18 orang $(60,0 \%)$ lebih besar yang tidak menggunakan kontrasepsi IUD sebanyak 12 responden (40,0\%) dari 17 responden yang berpengetahuan kurang baik menggunakan kontrasepsi IUD sebanyak 3 responden $(17,6 \%)$ lebih kecil dari yang tidak menggunakan kontrasepsi IUD sebanyak 14orang $(82,4 \%)$.

Tabel 5 Distribusi Responden Berdasarkan Dukungan Suami dan Penggunaan Kontrasepsi Intra Uterine Device(IUD) di Puskesmas Pedamaran Timur Kab. OKI Tahun 2018

\begin{tabular}{|c|c|c|c|c|c|c|c|c|}
\hline \multirow[t]{3}{*}{ No } & \multirow{3}{*}{$\begin{array}{l}\text { Dukungan } \\
\text { Suami }\end{array}$} & \multicolumn{4}{|c|}{ Penggunaan IUD } & \multirow{2}{*}{\multicolumn{2}{|c|}{ Total }} & \multirow[t]{3}{*}{$P$ Value } \\
\hline & & \multicolumn{2}{|c|}{ Ya } & \multicolumn{2}{|c|}{ Tidak } & & & \\
\hline & & $\mathbf{n}$ & $\%$ & $\mathbf{n}$ & $\%$ & $\mathbf{N}$ & $\%$ & \\
\hline 1 & Mendukung & 17 & 60,7 & 11 & 39,3 & 28 & 100 & 0,017 \\
\hline 2 & $\begin{array}{l}\text { Tidak } \\
\text { Mendukung }\end{array}$ & 4 & 21,1 & 15 & 78,9 & 19 & 100 & Bermakna \\
\hline & Jumlah & 21 & & 26 & & 47 & & \\
\hline
\end{tabular}

Berdasarkan hasil tabel 5 diatas, dapat dilihat dari 28 responden yang mendapatkan dukungan suami menggunakan kontrasepsi IUD sebanyak 17 orang $(60,7 \%)$ lebih besar yang tidak menggunakan kontrasepsi IUD sebanyak 11 responden (39,3\%) sedangkan dari 19 responden yang 
Jurnal Kebidanan : Jurnal Medical Science Ilmu Kesehatan Akademi Kebidanan Budi Mulia Palembang Volume.11 No.1, Juni 2021

Available online http://journal.budimulia.ac.id/

suaminya tidak mendukung menggunakan kontrasepsi IUD sebanyak 4 responden $(21,1 \%)$ lebih kecil yang tidak menggunakan kontrasepsi IUD sebanyak 15 orang $(78,9 \%)$.

Tabel 6 Distribusi Responden Berdasarkan Dukungan Suami dan Penggunaan Kontrasepsi Intra Uterine Device(IUD) di Puskesmas Pedamaran Timur Kab. OKI Tahun 2018

\begin{tabular}{|c|c|c|c|c|c|c|c|c|}
\hline \multirow[t]{3}{*}{ No } & \multirow{3}{*}{$\begin{array}{c}\text { Dukungan } \\
\text { Suami }\end{array}$} & \multicolumn{4}{|c|}{ Penggunaan IUD } & \multirow{2}{*}{\multicolumn{2}{|c|}{ Total }} & \multirow[t]{3}{*}{ P Value } \\
\hline & & \multicolumn{2}{|c|}{ Ya } & \multicolumn{2}{|c|}{ Tidak } & & & \\
\hline & & $\mathbf{n}$ & $\%$ & $\mathbf{n}$ & $\%$ & $\mathbf{N}$ & $\%$ & \\
\hline 1 & Mendukung & 17 & 60,7 & 11 & 39,3 & 28 & 100 & 0,017 \\
\hline 2 & $\begin{array}{c}\text { Tidak } \\
\text { Mendukung }\end{array}$ & 4 & 21,1 & 15 & 78,9 & 19 & 100 & Bermakna \\
\hline & Jumlah & 21 & & 26 & & 47 & & \\
\hline
\end{tabular}

Berdasarkan hasil tabel 6 diatas, dapat dilihat dari 28 responden yang mendapatkan dukungan suami menggunakan kontrasepsi IUD sebanyak 17 orang $(60,7 \%)$ lebih besar yang tidak menggunakan kontrasepsi IUD sebanyak 11 responden (39,3\%) sedangkan dari 19 responden yang suaminya tidak mendukung menggunakan kontrasepsi IUD sebanyak 4 responden $(21,1 \%)$ lebih kecil yang tidak menggunakan kontrasepsi IUD sebanyak 15 orang $(78,9 \%)$.

\section{PEMBAHASAN}

\section{Hubungan Tingkat Pengetahuan dengan Kontrasepsi IUDdi Puskesmas Pedamaran Timur Kab. OKI Tahun 2018}

Dari hasil penelitian pada analisis univariat didapatkan dari 47 responden dengan pengetahuan yang baik sebanyak 30 orang $(63,8 \%)$ lebih besar dibandingkan responden yang berpengetahuan kurang baik yaitu 17 orang $(36,2 \%)$

Dari hasil analisis bivariat dapat dilihat bahwadari 30 responden dengan ibu yang berpengetahuan baik menggunakan kontrasepsi IUD sebanyak 18 orang $(60,0 \%)$ lebih besar yang tidak menggunakan kontrasepsi IUD sebanyak 12 responden $(40,0 \%)$ dari 17 responden yang berpengetahuan kurang baik menggunakan kontrasepsi IUD sebanyak 3 responden $(17,6 \%)$ lebih kecil dari yang tidak menggunakan kontrasepsi IUD sebanyak 14 orang $(82,4 \%)$.

Berdasarkan hasil uji statistik $C h i$ Square pada batas $\alpha=0,05$ dan df $=1$ di dapat nilai $p$ value $=0,012<\alpha=0,05$ hal ini menunjukkan bahwa ada hubungan antara tingkat pengetahuan dengan menggunakan kontrasepsi IUD sehingga dengan demikian hipotesis yang menyatakan ada hubungan yang bermakna terbukti secara statistik.

Penelitian ini sejalan denganpenelitian Sri Mularsih, dkk (2018) hasil analisis data penelitian menggunakan uji bivariat $C h i$ Square yang dilanjutkan dengan uji Kolmogorov Smirnov, diperoleh hasil bahwa ada hubungan yang bermakna antara tingkat pengetahuan PUS tentang kontrasepsi AKDR dengan pemilihan kontrasepsi AKDR, dengan nilai $p=0,000$. Hasil tersebut berarti nila $\mathrm{p}<0,05$ sehingga Ha diterima.

Penelitian ini sejalan dengan penelitian Rahayu (2018). Hasil penelitian ini menunjukkan bahwa dari 59 responden yang memiliki pengetahuan tinggi, terdapat 11 responden $(18,6 \%)$ menggunakan kontrasepsi IUD. Sementara itu dari 30 responden yang memiliki pengetahuan rendah, terdapat 29 responden (96,7\%) tidak menggunakan kontrasepsi IUD. Uji statistic Chi-Square didapatkan hasil bahwa adanya hubungan pengetahuan Ibu Pasangan Usia subur dengan Penggunaan Kontrasepsi IUD di Nagari Andalas Baruh Bukit Kecamatan Sungayang Kabupaten Tanah Datar dimana nilai $p=0,050(p \leq 0,050)$. 
Penelitian ini sejalan dengan penelitian Pitriani (2015) Ada hubungan antara pengetahuan dengan penggunaan kontrasepsi IUD ( $\mathrm{p}$ value $=0,036)$, dengan $\mathrm{OR}=7,893$ (95\%CI: 963-64,685) artinya ibu dengan tingkat pengetahuan yang rendah beresiko 7 kali tidak menggunakan kontrasepsi 1UD daripada yang berpengetahuan tinggi.

\section{Hubungan Dukungan Suami dengan Penggunaan Kontrasepsi IUD di Puskesmas Pedamaran Timur Kab. OKI tahun 2018}

Dari hasil penelitian pada analisis univariat didapatkan dari 47 responden dengan ibu yang mendapat dukungan suami sebanyak 28 orang $(59,6 \%)$ dan ibu yang tidak mendapatkan dukungan dari suami sebanyak 19 orang $(40,4 \%)$.

Dari hasil analisis bivariat dapat dilihat bahwa dari 28 responden yang mendapatkan dukungan suami menggunakan kontrasepsi IUD sebanyak 17 orang $(60,7 \%)$ lebih besar yang tidak menggunakan kontrasepsi IUD sebanyak 11 responden $(39,3 \%)$ sedangkan dari 19 responden yang suaminya tidak mendukung menggunakan kontrasepsi IUD sebanyak 4 responden $(21,1 \%)$ lebih kecil yang tidak menggunakan kontrasepsi IUD sebanyak 15 orang $(78,9 \%)$.

Berdasarkan hasil uji statistik chi square pada batas $\alpha=0,05$ dan df $=1$ di dapat nilai $p$ value $=0,017<\alpha=0,05$ hal ini menunjukkan bahwa ada hubungan antara dukungan suami dengan menggunakan kontrasepsi IUD sehingga dengan demikian hipotesis yang menyatakan ada hubungan yang bermakna terbukti secara statistik.

Penelitian ini sejalan dengan penelitian Sulastri 2014 bahwa responden yang tidak mendapatkan dukungan suami dan mempunyai minat rendah sebesar 90,9\% lebih tinggi dibandingkan responden yang mendapatkan dukungan suami dengan minat rendah yaitu sebesar 62,2\%. Sedangkan responden yang mendapatkan dukungan suami dan mempunyai minat tinggi sebesar $20 \%$ lebih banyak dibandingkan responden yang tidak mendapatkan dukungan suami dan mempunyai minat tinggi sebesar $4,5 \%$. Berdasarkan uji Chi Square didapat nilai $\chi^{2}$ hitung sebesar 10,162 dengan $\mathrm{p}$-value 48 0,006 . Oleh karena p-value $=0,006<\alpha$ $(0,05)$, maka Ho ditolak, dan disimpulkan bahwa ada hubungan yang signifikan antara dukungan suami dengan minat ibu dalam pemakaian kontrasepsi IUD di Bergas

Penelitian ini sejalan dengan Penelitian Bernadus dkk (2013) didapatkan hasil bahwa dukungan suami mempunyai hubungan yang bermakna dengan pemilihan AKDR di Puskesmas Jailolo. Berdasarkan hasil uji statistik yang dilakukan diketahui $\mathrm{p}=0,041$ $(\mathrm{p}<0,05)$.

Penelitian ini sejalan dengan penelitian Rahayu (2012) Hasil penelitian menggambarkan suami mendukung penggunaan Kontrasepsi IUD 48 (55,8\%), sedangkan suami yang tidak mendukung hanya $38(44,2 \%)$. Analisis bivariat didapatkan $48 \quad(55,8 \%)$ yang mendapat dukungan suami menggunakan kontrasepsi IUD, sedangkan yang mendapat dukungan suami tetapi tidak menggunakan kontrasepsi IUD sebanyak 39 responden $(45,3 \%)$. Hasil uji statistik nilai $\mathrm{p}$ value 0,004 berarti ada hubungan antara dukungan suami dengan penggunaan kontrasepsi IUD pada akseptor wanita

\section{KESIMPULAN}

Berdasarkan uraian hasil penelitian dan pembahasan mengenai hubungan tingkat pengetahuan, dukungan suami dengan penggunaan kontrasepsi IUD di Puskesmas pedamaran Timur Kab. OKI Tahun 2018. dengan jumlah sampel penelitian sebanyak 47akseptor.Dapat disimpulkan bahwa Ada hubungan tingkat pengetahuan dengan penggunaan kontrasepsi IUD di Puskesmas pedamaran Timur Kab. OKI Tahun 2018 dengan $\mathrm{p}$ value $0,012<0,05$ dan ada hubungan dukungan suami dengan penggunaan kontrasepsi IUD di Puskesmas pedamaran Timur Kab. OKI Tahun 2018 dengan $\mathrm{p}$ value $0,017<0,05$. 


\section{DAFTAR PUSTAKA}

Aspuah, Siti.dkk.2010. Panduan Pemilih Kontrasepsi. Yogyakarta. Muha Medika

Atikah, dkk. 2010. Panduan Memilih Kontrasepsi. Nuha Medica. Yogyakarta.

Arum, D N Setya dan Sujiyatini. 2011. Panduan Lengkap Pelayanan KB Terkini. Jogyakarta : Nuha Medika.

Nugroho, T. Dan Bobby, I.U. 2014. Masalah Kesehatan Reproduksi Wanita. Yogyakarta. Nuha medika.

Setyorini, A. 2014. Kesehatan Reproduksi dan Pelayanan Keluarga Berencana. Bogor : In Media.

Handayani, S. 2010. Buku Ajar Pelayanan Keluarga Berencana. Yogyakarta: Pustaka Rihama.

Hartanto, H. 2013. Keluarga Berencana dan Kontrasepsi. Sinar Harapan. Jakarta.

Hidayati, 2011. Metode dan Tekhnik Penggunaan Alat Kontrasepsi, Salemba Medika Jakarta.

Varney, H. 2006. Asuhan Kebidanan, EGC : Jakarta.

Notoadmodjo, 2010. Metode Penelitian Kesehatan, Aneka Cipta Jakarta.

Pinem, Saroha. 2014. Kesehatan Reproduksi dan Kontrasepsi, Trans Info Medika Jakarta.

2009. Kesehatan Reproduksi dan Kontrasepsi, Trans Info Medika Jakarta.

Profil Puskesmas Pedamaran Timur Tahun 2019.
Profil Dinkes Ogan Komering Ilir tahun 2019.

Proverawati, A. 2010. Panduann Memilih Kontrasepsi. Yogyakarta : Nuha Medika.

Saifuddin, 2006. Buku Panduan Praktis Pelayanan Kontrasepsi, Bina Pustaka Sarwono Prawirohardjo Jakarta.

Sibagariang dkk, 2010. Buku Saku Metode Penelitian, Trans Info Medika Jakarta.

Sulistyawati, 2011. Pelayanan Keluarga Berencana, Salemba Medika Jakarta.

Bernades. 2013.

http://ejournal.unsrat.ac.id/index.php /eners/article/view/1760/1401 (Jurnal e-NERS (eNS), Volume 1,Nomor 1, Maret 2013, hlm. 1-10. Diakses pada tanggsl 15 Mei 2018.

Dinkes Provinsi 2015. Pdf. Diakses pada tanggsl 15 Mei 2018.

Humairah, 2011. Keluarga Berencana, http://kauhumairah.blogspot.com/201 1/02/keluarga-berencana.html.Data diakses tanggal. 27 April 2018.

Humas, 2012. http://setkab.go.id/sudahtembus-149-bkkbn-ingin-lajupertumbuhan-penduduk-bisaditekan-jadi-11/Diakses pada tanggsl 15 Mei 2018.

SDKI. 2012. Pdf. Diakses pada tanggsl 15 Mei 2018.

Suparyanto, 2011. Sekilas Tentang Keluarga Berencana,

Drsuparyanto.blogspot.com/search/1 abel/keluarga\%20berencana?pdatd$\max =20130502 \mathrm{~T} 06: 18: 00 \% 2 \mathrm{~B} 07 ; 00$ $\&$ maxresult $=20 \&$ start $=2 \&$ bydate $=$ fa 
Jurnal Kebidanan : Jurnal Medical Science Ilmu Kesehatan Akademi Kebidanan Budi Mulia Palembang Volume.11 No.1, Juni 2021

Available online http://journal.budimulia.ac.id/

lse. Diakses pada tanggsl $15 \mathrm{Mei}$

2018.

Nurparidah. 2014.

http://jumpakebidanan.blogspot.co.i

d/2014/01/senggama-

terputus.html.Diakses pada tanggsl

15 Mei 2018.

Suryadh,

2009.https://suryadh.wordpress.com

/2009/11/12/macam-macam-alat-

kontrasepsi. Diakses pada tanggsl 15

Mei 2018

BKKBN. 2012. http://www.bkkbnjatim.go.id/bkkbnjatim/html/infokb.htm. Diakses pada tanggsl 15 Mei 2018. 
